\title{
‡USES
}

science for a changing world

Prepared in cooperation with the

Florida Department of Environmental Protection and the

Southwest Florida Water Management District

\section{Water Quality and Evaluation of Pesticides in Lakes in the Ridge Citrus Region of Central Florida}

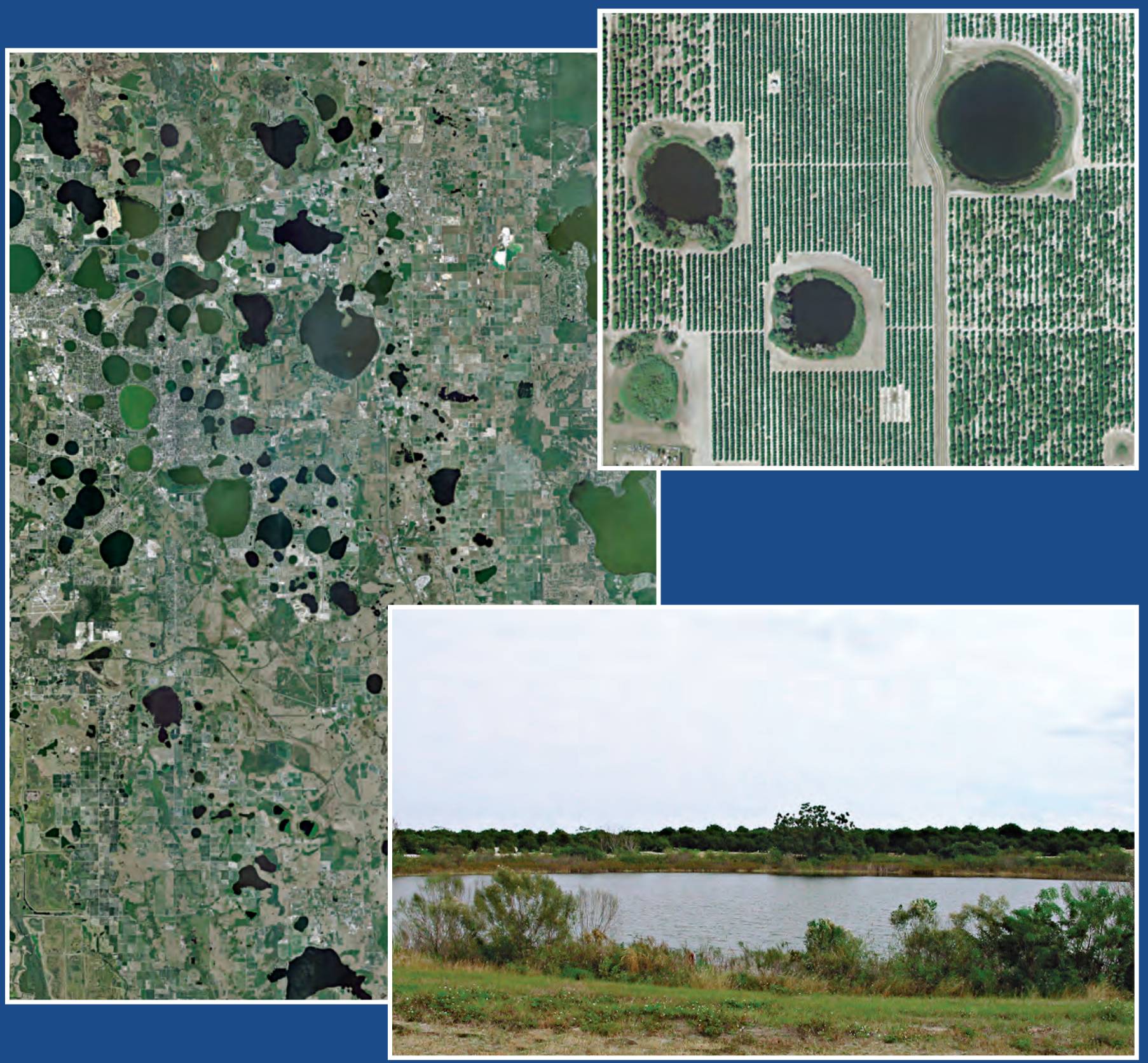

\section{Scientific Investigations Report 2008-5178}

U.S. Department of the Interior

U.S. Geological Survey 


\section{Report Cover-}

Left: Satellite view of lakes in central Polk County, Florida-- about 60 miles altitude; approximate scale, 1 in.= 6 mi. (2007 natural-color, digital orthophotograph, Florida State University, 2008; Southwest Florida Water Management District, 2008)

Upper right: Satellite view of Swim Lake (upper right) and nearby lakes in Polk County, Florida, surrounded by citrus groves; approximate scale, 1 in. $=800 \mathrm{ft}$. (2007 natural-color, digital orthophotograph, Florida State University, 2008; Southwest Florida Water Management District, 2008).

Lower right: Photograph of Swim Lake, Florida, and surrounding citrus agriculture [courtesy of Sharon Kroening, U.S. Geological Survey]. 


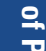

